\title{
Tax System, Replacement Rate of Pension and Child Allowance
}

\author{
Masatoshi Jinno ${ }^{1} \&$ Masaya Yasuoka ${ }^{2}$ \\ ${ }^{1}$ Faculity of Policy Management, Shobi University, Saitama, Japan. \\ ${ }^{2}$ School of Economics, Kwansei Gakuin University, Hyogo, Japan. \\ Correspondence: Masaya Yasuoka, School of Economics, Kwansei Gakuin University, 1-155 Uegahara Ichiban-Cho, \\ Nishinomiya, Hyogo, 662-8501 Japan. Tel.: +81-798-54-6993.
}

Received: March 31, 2016

doi:10.11114/aef.v3i3.1583
Accepted: April 26, 2016

Available online: April 29, 2016

URL: http://dx.doi.org/10.11114/aef.v3i3.1583

\section{Abstract}

This paper examines an endogenous fertility model with the aim of investigating how the tax burden necessary to finance pension benefits and a child-care support policy affects fertility and the replacement rate of pension in the steady state with theoretical analyses and numerical examples. The results presented in this paper are as follows. Without child allowance, income taxation can not raise the replacement rate largely. However, consumption taxation can raise the replacement rate largely. In Japan, the government sets the replacement rate as 50\%. In terms of welfare, the pension benefit should be financed by consumption taxation and child allowance should be provided to achieve the replacement rate $50 \%$.

Keywords:Endogenous fertility, Child allowance, Replacement rate of pension

\section{Introduction}

Some developed countries are faced with an aging society with fewer children, as described by Sleebos (2003). In Japan, fertility continued decreasing in post-war period and reached 1.26 at 2005. Even if fertility in Japan increases slightly in the near future, fertility is expected to remain at a low level for the foreseeable future. Figure 1 shows the total fertility rates for several developed countries.

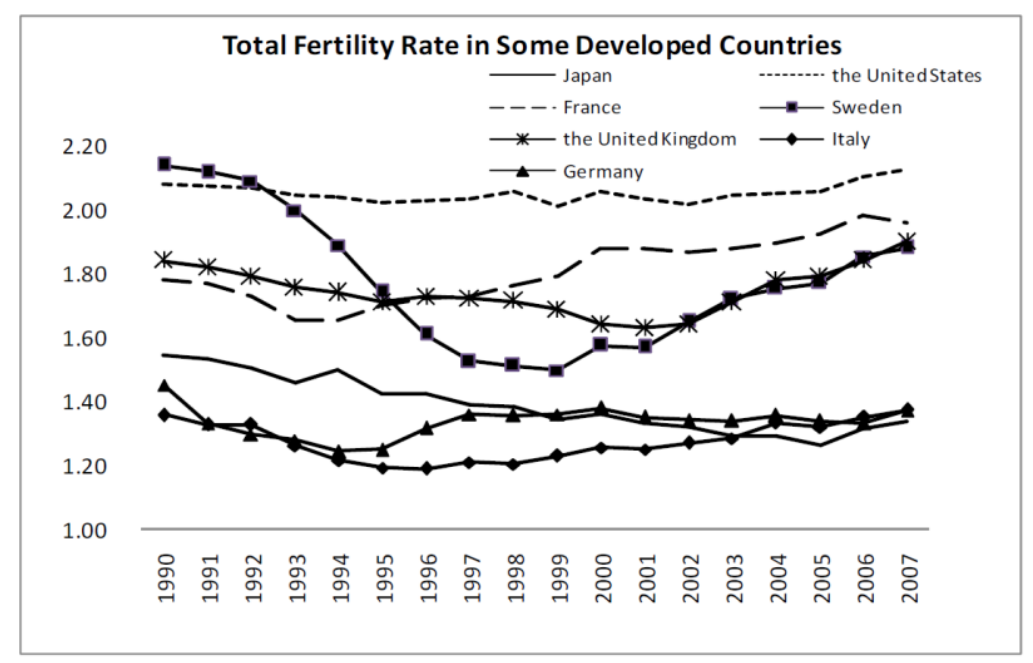

Fig. 1 Total Fertility Rate in Some Developed Countries ${ }^{1}$

In developed countries, France, Sweden, the United Kingdom, and the United States show higher total fertility rates than Germany, Italy, or Japan. Particularly, France, Sweden, and the United Kingdom have succeeded in raising fertility. These countries provide sufficient family support, as shown by Fig. 2.

${ }^{1}$ Data: Demographic Yearbook (UN), Population Statics (National Institute of Population and Social Security Research, Japan), Vital Statistics in Japan (Ministry of Health, Labour and Welfare, Japan ) and White Paper on Birthrate-Declining Society (Cabinet Office, Japan) 


\section{Fiscal Support For Family (2003) Ratio to GDP(\%)}

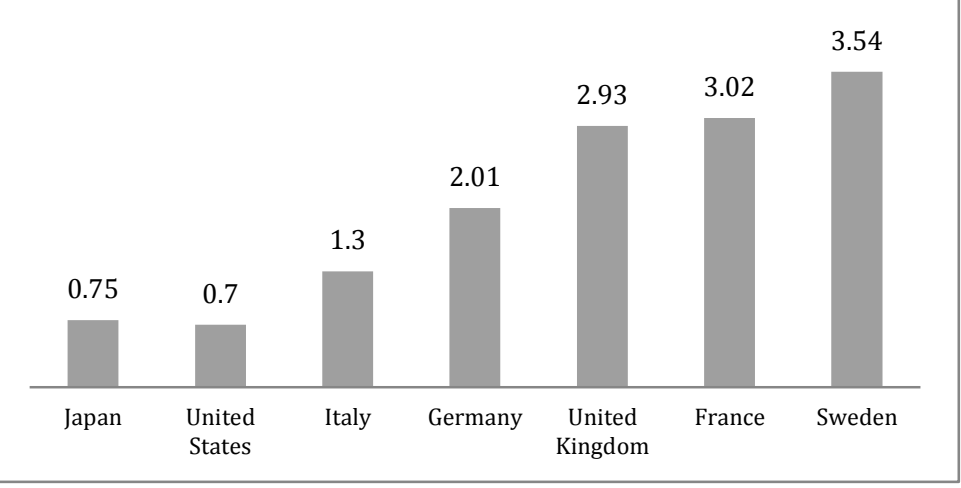

Fig.2 Fiscal Support for Family Ratio to GDP ${ }^{2}$

Financial incentives such as a child allowance can increase fertility, as demonstrated by Lutz (1999), Milligan (2002), and Laroque and Salanie (2005). In addition to financial incentives to have children, the compatibility between working and child care is an important factor determining fertility. In France and Sweden, child-care service is provided sufficiently that parents need not stop working to provide child care. However, in Japan, the compatibility is insufficient. Therefore, parents can not have children because the opportunity cost for child care is higher than in either France or Sweden.

Some reasons occurred an aging society with fewer children exist. One is social security. Thanks to social security, parents do not have to depend on their children to care their old life. Therefore, parents reduce the demand for children as investment goods. Nishimura and Zhang (1992), Zhang and Zhang (1998), Wigger (1999) and Oshio and Yasuoka (2009) set the model considered children as investment goods and derived that pay-as-you-go pension system reduces the fertility. Zhang and Zhang (2004) examined the correlation between social security and the fertility empirically and showed the negative correlation.

Why is the fewer children bad? The reason has to do with sustainability of social security such as pension system and so on. Decrease in fertility means small size of younger people in future and social security can not support for older people. Therefore, the government must pull up the fertility with child-care support policy to be easy to have children for parents. This paper shows how the government collects tax revenue and provides a child allowance to pull up the replacement rate for pension benefit. Developed countries reforms pension system. In Japan, the government reformed pension system at 2004. A reformed pension system adopts macroeconomic slide system (pension benefit depends on macroeconomic factor, such as population growth.) and fixed contribution rate (Defined Contribution). The replacement rate of pension benefit is set at 50\% (standard households). It is important to examine how the government collects the revenue to provide pension benefit and provide a child care policy to achieve this replacement rate. This paper aims to examine about this.

Not to say, earlier studies examined the effects of family support policy on the fertility. ${ }^{3}$ Van Groezen, Leers and Meijdam (2003) and van Groezen and Meijdam (2008) insisted on an importance of child allowance. Thanks to child allowance, the fertility increases. Oshio (2001) and Yasuoka (2006) showed that child allowance increases the fertility, too. However, Fanti and Gori (2009) showed child allowance decreases the fertility in the steady state even if the fertility increases in short run, that is, child allowance is not always desirable to pull up the fertility. ${ }^{4}$ Zhang and Zhang (2007) set the endogenous fertility model included unfunded pension system and derived optimal pension. In Zhang and Zhang (2007), the fertility determined in decentralized economy is more than the socially optimal fertility, and then the government must reduce the fertility and increase income growth. This result means that child allowance is harmful in terms of social optimal allocations.

The result presented in this paper are as follows. Child allowance increases the fertility and the replacement rate. Without child allowance, income taxation can not achieve the replacement rate aimed in Japan. Therefore, child allowance should be provided to hold the replacement rate. On the other hand, consumption taxation can achieve the

\footnotetext{
${ }^{2}$ Data: OECD Social Expenditure Database (2007). The data of Fiscal Support for Family are at 2003. Fiscal Support for Family contains kind benefit (day-care/home help and other benefits in kind) and cash benefit (family allowance, maternity and parental leave and other cash benefit).

${ }^{3}$ Family support policies are considered in the model with unfunded pension system. Although Hirazawa and Yakita (2009) set the model without family support policy, they derived that a decrease in labor income tax to finance pension benefit can pull up household's utility level.

${ }^{4}$ Fanti and Gori (2009) considered child tax (that is, negative child allowance) and derived that the fertility is increased by child tax. This result shows that positive child allowance decreases the fertility.
} 
replacement rate aimed in Japan even if the government does not provide a child allowance. However, child allowance can raise social welfare for any replacement rate. Therefore, the pension benefit should be collected by consumption taxation and the government should provide child allowance. ${ }^{5}$

The remainder of this paper is presented as follows: Section 2 introduces the model. Section 3 presents a description of the equilibrium. Section 4 uses numerical examples and examines how tax burden and child allowance affect the fertility, capital accumulation, the replacement rate and welfare. The final section explains the conclusions of this study.

\section{The Model}

The model economy consists of a two-period (young and old) overlapping generations model. Agents of three types exist: households, firms, and a government.

\subsection{Households}

Households experience two periods: young and old. During the young period, each household supplies labor inelastically to earn labor income. Households care about the quantity of children and consumption during the young and old period. Households must save to consume during the old period. In addition to household behavior, the government levies a labor income tax and a consumption tax to provide pension benefits, a child allowance. Pension benefits are provided for older people, but a child allowance is provided for younger people. Then, the household's lifetime budget constraint is shown as follows:

$$
\left(1+\tau_{c}\right) c_{1 t}+\frac{\left(1+\tau_{c}\right) c_{2 t+1}}{1+r_{t+1}}+\left(z_{t}-q_{t}\right) n_{t}=(1-\tau) w_{t}+\frac{p_{t+1}}{1+r_{t+1}}
$$

Therein, $c_{1 t}$ and $c_{2 t+1}$ respectively denote consumption during the young period and the one in the old period. In addition, $r_{t+1}$ represents an interest rate, $w_{t}$ denotes the wage rate per unit of labor, $\tau$ and $\tau_{c}$ respectively represent the labor income tax rate and the consumption tax rate $\left(0<\tau, \tau_{c}<1\right)$, and $z_{t}$ denotes the child-care cost, which is assumed $z_{t} \equiv \hat{z} w_{t}(0<\hat{z}){ }^{6}$ The government provides $q_{t}$ unit of child allowance for a child. A child allowance $q_{t}$ is given as $\hat{q} w_{t} . \hat{q}$ denotes the subsidy rate of the child allowance, which is assumed as $0<\hat{q}<\hat{z}$. Older people can receive pension benefit $p_{t+1}$.

A household's utility function $u_{t}$ is given as follows,

$$
u_{t}=\alpha \operatorname{lnn} n_{t}+\beta \ln c_{1 t}+(1-\alpha-\beta) \ln c_{2 t+1}, 0<\alpha, \beta<1 .
$$

A household chooses consumption during young and old life $c_{1 t}, c_{2 t+1}$ and chooses fertility $n_{t}$ to maximize lifetime utility (2) subject to the lifetime budget constraint (1). The first-order condition derives the following equations.

$$
\begin{gathered}
c_{1 t}=\frac{\beta}{1+\tau_{c}}\left[(1-\tau) w_{t}+\frac{p_{t+1}}{1+r_{t+1}}\right], \\
c_{2 t+1}=\frac{\left(1+r_{t+1}\right)(1-\alpha-\beta)}{1+\tau_{c}}\left[(1-\tau) w_{t}+\frac{p_{t+1}}{1+r_{t+1}}\right], \\
n_{t}=\frac{\alpha}{\hat{z}-\hat{q}}\left[(1-\tau)+\frac{p_{t+1}}{\left(1+r_{t+1}\right) w_{t}}\right] .
\end{gathered}
$$

With an increase in child-care cost $(\hat{z}-\hat{q}) w_{t}$, the quantity of children (fertility) decreases.

\subsection{Firms}

The production function of final goods is given as a neoclassical constant-return-to-scale function:

$$
Y_{t}=A K_{t}^{\theta} L_{t}^{1-\theta}, 0<A, 0<\theta<1 .
$$

In that equation, $Y_{t}$ and $K_{t}$ respectively represent the final goods and capital stock. Moreover, $L_{t}$ denotes labor input.

\footnotetext{
5 Miyazato (2010) derived an optimal replacement rate in the model which is based on risks of longevity and volatility of return on assets.

${ }^{6}$ Van Groezen and Meijdam (2008) assumed and examined that child-care cost $z_{t}$ depends on the wage rate. If we regard $z_{t}$ as the child-care service cost, it is natural that $z_{t}$ depends on the wage rate.
} 
Defining $N_{t}$ as the younger population size in $t$ period, labor input is $L_{t}=N_{t}$. Assuming perfect competition, the wage rate $w_{t}$ and the interest rate $r_{t}$ are

$$
\begin{gathered}
w_{t}=A(1-\theta) k_{t}^{\theta}, \\
1+r_{t}=A \theta k_{t}^{\theta-1},
\end{gathered}
$$

where $k_{t}$ denotes capital per capita defined as $k_{t} \equiv \frac{K_{t}}{N_{t}}$. The capital stock is assumed to be fully depreciated in one period.

\subsection{Government}

The Government collects tax revenue by income tax and consumption tax to provide pension benefit and child allowance. Defining $\tau=\tau_{p}+\tau_{q}$, which $\tau_{p}$ denotes income tax rate to provide pension benefit and $\tau_{q}$ denotes income tax to provide child allowance. Considering balanced budget, the government budget constraints financed by income tax are shown as follows,

$$
\begin{gathered}
p_{t}=n_{t-1} \tau_{p} w_{t}, \\
\tau_{q t}=\hat{q} n_{t} .
\end{gathered}
$$

$p_{t}$ and $\tau_{q}$ are determined to hold budget constraints. If the government collects tax revenue by consumption tax,

$$
\begin{gathered}
p_{t}=\frac{\tau_{c p}(\hat{z}-\hat{q})}{\alpha\left(1+\tau_{c}\right)} n_{t-1}\left[\beta n_{t}+(1-\alpha-\beta)\left(1+r_{t}\right)\right], \\
\tau_{c q t}=\frac{1+\tau_{c p}}{\frac{(\hat{z}-\hat{q})\left[\beta n_{t}+(1-\alpha-\beta)\left(1+r_{t}\right)\right]}{\alpha \hat{q} w_{t} n_{t}}-1},
\end{gathered}
$$

where $\tau_{c} \equiv \tau_{c p}+\tau_{c q t} \cdot p_{t}$ and $\tau_{c q}$ are determined to hold budget constraints.

\section{Equilibrium}

This section derives the equilibrium in this model economy. First, we derive the equilibrium with income taxation. After this analyses, we derive the one with consumption taxation.

\subsection{Equilibrium with Income Taxation}

We derive the dynamics of physical capital. Considering the capital market equilibrium condition $K_{t+1}=N_{t} s_{t}, k_{t+1}$ are shown as

$$
k_{t+1}=\frac{A \theta(1-\theta)}{\theta+\beta \tau_{p}(1-\theta)}\left[\frac{(1-\beta)\left((\hat{z}-(1-\alpha) \hat{q})\left(\theta+\beta \tau_{p}(1-\theta)\right)+\alpha \tau_{p}(1-\theta)(\hat{z}-\beta \hat{q})\right)}{\alpha\left(\theta+(1-\theta) \tau_{p}\right)}-(\hat{z}-\beta \hat{q})\right] k_{t}^{\theta},
$$

where $s_{t}$ denotes household saving, i.e., $s_{t} \equiv(1-\tau) w_{t}-(\hat{z}-\hat{q}) w_{t} n_{t}-c_{1 t}$. The fertility $n_{t}$ is constant over time as shown by

$$
n_{t}=\frac{\alpha\left(1-\tau_{p}\right)\left(\theta+(1-\theta) \tau_{p}\right)}{(\hat{z}-(1-\alpha) \hat{q})\left(\theta+\beta \tau_{p}(1-\theta)\right)+\alpha(1-\theta)(\hat{z}-\beta \hat{q}) \tau_{p}}
$$

The replacement is given by

$$
\frac{p_{t+1}}{w_{t}}=\tau_{p} n_{t}
$$

which is constant over time because of (14) and (15). Therefore, this dynamic system is specified by $k_{t}$. There exists a stable steady state as shown by (13). The capital per capita in the steady state $k$ is shown by 


$$
k=\left[\frac{A \theta(1-\theta)}{\theta+\beta \tau_{p}(1-\theta)}\left(\frac{(1-\beta)\left((\hat{z}-(1-\alpha) \hat{q})\left(\theta+\beta \tau_{p}(1-\theta)\right)+\alpha \tau_{p}(1-\theta)(\hat{z}-\beta \hat{q})\right)}{\alpha\left(\theta+(1-\theta) \tau_{p}\right)}-(\hat{z}-\beta \hat{q})\right)\right]^{\frac{1}{1-\theta}}
$$

Considering (14), we obtain $\frac{d n}{d \widehat{q}}>0$, that is, child allowance can raise the fertility, therefore, replacement rate increases, too. As shown by (14), an increase in $\tau_{p}$ can not always increase the replacement rate. An increase in $\tau_{p}$ raises the rate directly. However, an increase in $\tau_{p}$ may reduce the fertility, so that the replacement rate may decrease. The effect of child allowance on capital per capita is ambiguous.

\subsection{Equilibrium with Consumption Taxation}

We derive the dynamics of physical capital as follows,

$$
\frac{k_{t+1}}{w_{t}}=\frac{\frac{1-\beta}{n_{t}}-\frac{\beta \tau_{c p}(\hat{z}-\hat{q})(1-\alpha-\beta)}{\alpha\left(1+\tau_{c p}+\tau_{c q t}\right)}-(\hat{z}-\hat{q})}{1+\frac{\beta^{2} \tau_{c p}(1-\theta)(\hat{z}-\hat{q})}{\alpha \theta\left(1+\tau_{c p}+\tau_{c q t}\right)} n_{t+1}} .
$$

The fertility is derived as follows

$$
n_{t}=\frac{\alpha}{\hat{z}-\hat{q}}+\frac{\tau_{c p} n_{t}}{1+\tau_{c p}+\tau_{c q t}}\left[\frac{\beta(1-\theta) n_{t+1}}{\theta}+1-\alpha-\beta\right]
$$

where

$$
\tau_{c q t}=\frac{\alpha\left(1+\tau_{c p}\right) \hat{q}}{\frac{\beta \theta(\hat{z}-\hat{q})(1-\alpha-\beta) w_{t-1}}{(1-\theta) k_{t} n_{t}}-\alpha \hat{q}}
$$

The replacement rate is shown by

$$
\frac{p_{t+1}}{w_{t}}=\frac{(\hat{z}-\hat{q}) \tau_{c p} n_{t}}{\alpha\left(1+\tau_{c p}+\tau_{c q t}\right)}\left[\frac{\beta n_{t+1} w_{t+1}}{w_{t}}+(1-\alpha-\beta)\left(1+r_{t+1}\right)\right] .
$$

The capital per capita and the fertility in the steady state, $k=k_{t+1}=k_{t}$ and $n=n_{t+1}=n_{t}$ are given by (7), (8), (17)-(20). ${ }^{7}$ Being different from the equilibrium with income taxation, the effect of child allowance on the fertility, capital per capita and replacement rate are ambiguous. In the following section, we compute how tax burden or child allowance affect replacement rate and the fertility with numerical examples.

\section{Replacement Rate and Child Allowance}

This section examines how tax burden or child allowance affect replacement rate, fertility, capital per capita and welfare with numerical examples.

\subsection{Parameter Setting}

Based on de la Croix and Doepke (2003), we describe a parametric condition for numerical examples as $\alpha=0.075, \beta=$ $0.735, \theta=0.3, \hat{z}=0.075$ and $A=1$. We set child-care cost $\hat{z}$ as 0.075 . In fact, de la Croix and Doepke (2003) referred Haveman and Wolfe (1995) and Knowles (1999) to derive $0.075 w_{t}$ as child-care opportunity cost. Then, the analyses in the present paper set $\theta=0.3$ based on the recent labor income share in Japan. ${ }^{8}$ Derived by de la Croix and Doepke (2003), we set parameter $1-\alpha-\beta=0.19$, which is standard in real-business-cycle model and means that discount factor is 0.99 per quarter.

This paper considers the parameter to hold $\mathrm{n}=1$ that population size does not grow in developed countries, which de la Croix and Doepke (2003) also considered. We established parameter as $\alpha=0.075$ and $\beta=0.735$. Final, we set $A=1$

${ }^{7}$ The stable condition at $\hat{q}=0$ is $\frac{d n_{t+1}}{d n_{t}}=\frac{1+\frac{\tau_{c p}}{1+\tau_{c p}}\left[\frac{\beta(1-\theta) \hat{z} n}{\theta}-1+\alpha+\beta\right]}{\frac{\tau_{c p} \beta(1-\theta)(1-\beta-\hat{z} n)}{\left(1+\tau_{c p}\right) \theta}}$.

${ }^{8}$ Data: Annual Report on Japanese Economy and Public Finance. 
as unity. ${ }^{9}$

\subsection{Results}

Compared income taxation with consumption taxation, this subsection analyzes the results of numerical examples in the steady state. First, we consider the replacement rate. If pension is financed by income taxation, replacement rate increases with income tax rate in small tax rate. However, if income tax rate is high, the replacement rate decreases. On the other hand, consumption tax can raise the replacement rate even if consumption tax rate is high. This reason is explained by the fertility.

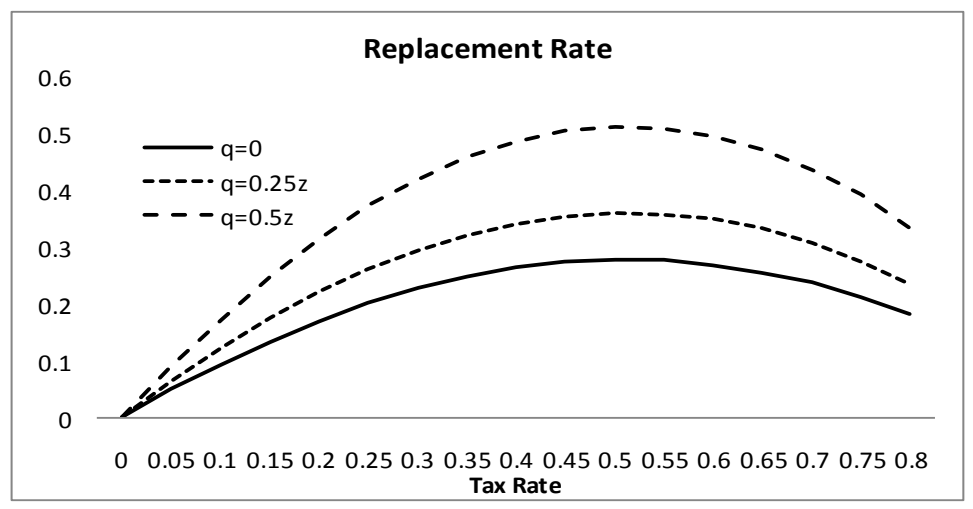

Fig.3-1. Replacement Rate (Income Taxation)

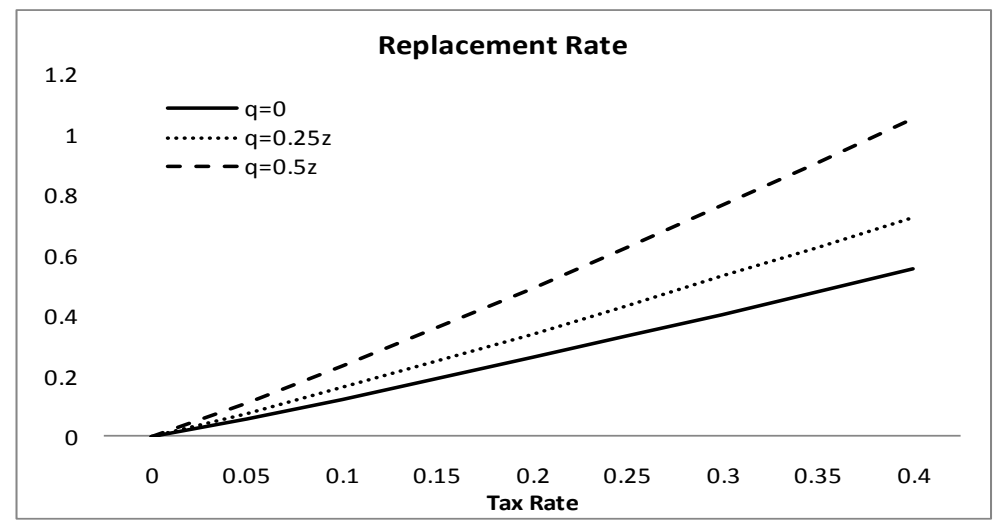

Fig.3-2. Replacement Rate (Consumption Taxation)

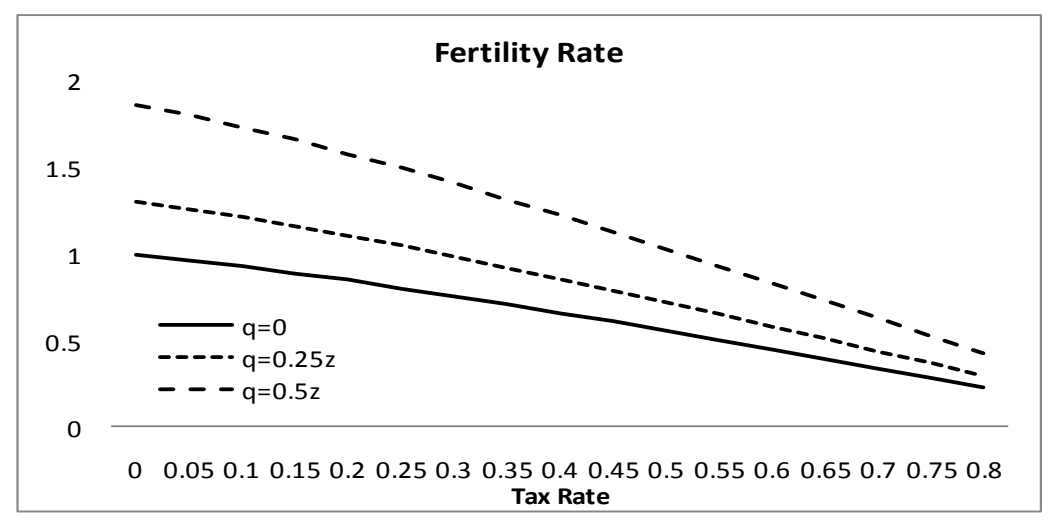

Fig.4-1 Fertility Rate (Income Taxation)

\footnotetext{
9 Even if this paper set the other parameters as $A$, the result derived in this paper does not changes substantially though the level of variables (welfare, the fertility) changes. An interest rate does not depend on $A$, as shown by (8) and (16).
} 


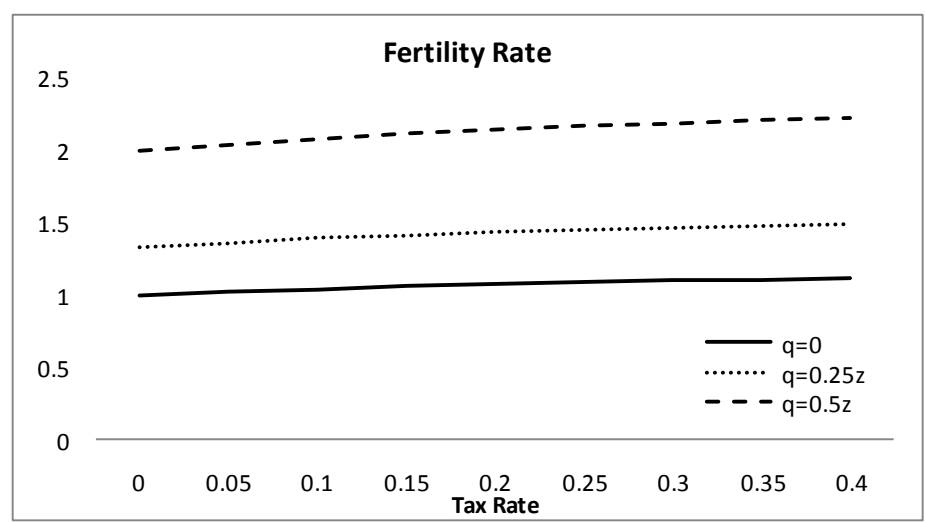

Fig.4-2. Fertility Rate (Consumption Taxation)

In income taxation, the fertility decreases with an increase in income tax rate. An increase in income tax rate decreases household's income, then the fertility reduces. An increase in income tax rate decrease household's disposable income directly. In addition, as shown by Fig.5, income taxation prevents capital accumulation, which reduces wage rate.

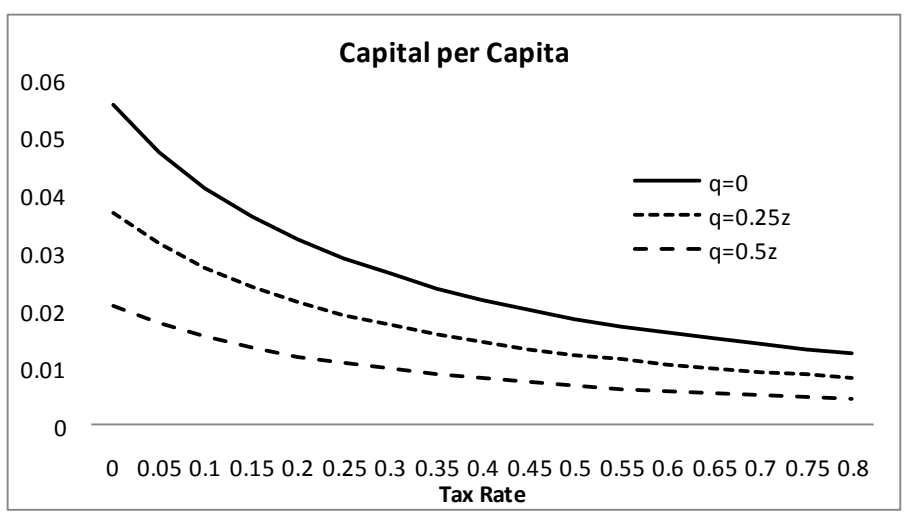

Fig. 5-1. Capital per Capita (Income Taxation)

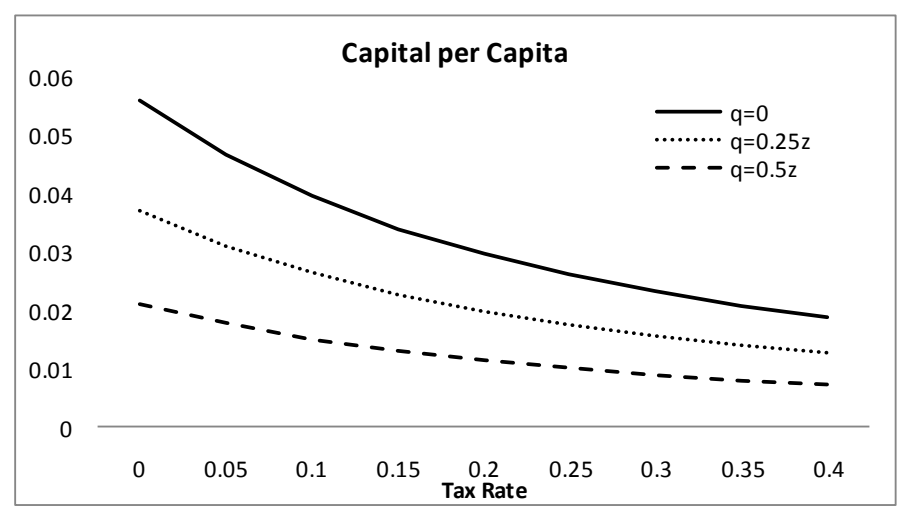

Fig.5-2. Capital per Capita (Consumption Taxation)

However, if the pension is financed by consumption tax, the fertility does not decrease. As shown by the case in income taxation, consumption tax decreases capital per capita. Therefore, consumption tax decreases household's disposable income as shown by the case of income taxation. On the other hand, being different from income taxation, an increase in consumption tax does not decrease household's income directly. Even if wage rate decreases, the fertility increases thanks to an increase in life time income brought about by pension benefit. Because the fertility does not decrease, consumption tax can raise the replacement rate even if the tax burden is high. Therefore, if the replacement rate must be set at high level, it should be financed not by income taxation but consumption tax. A child allowance can raise the replacement rate for any tax rate. Therefore, if child allowance is provided, the replacement rate rises without increase in tax burden for 
pension.

How does the government set child allowance and tax rate to hold the replacement rate? We define the utility level in the steady state as welfare. Considering welfare, no pension system maximizes the welfare.

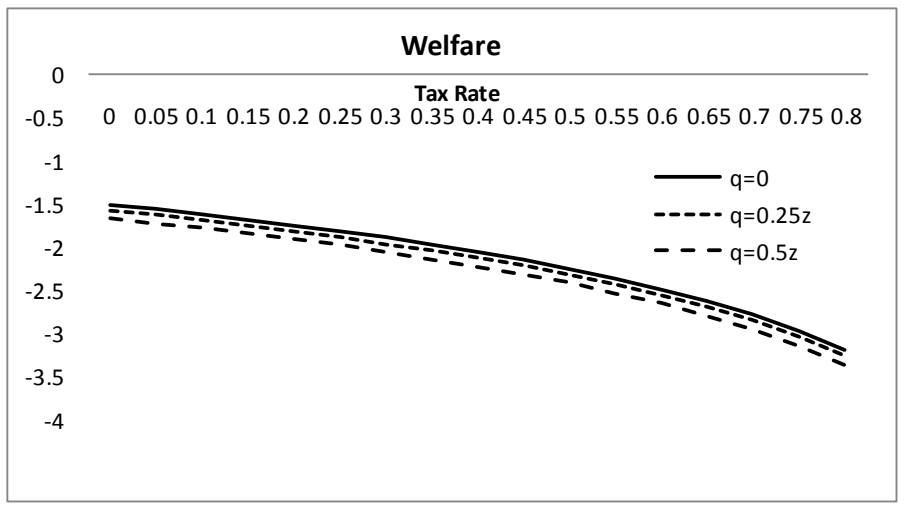

Fig.6-1. Welfare (Income Taxation)

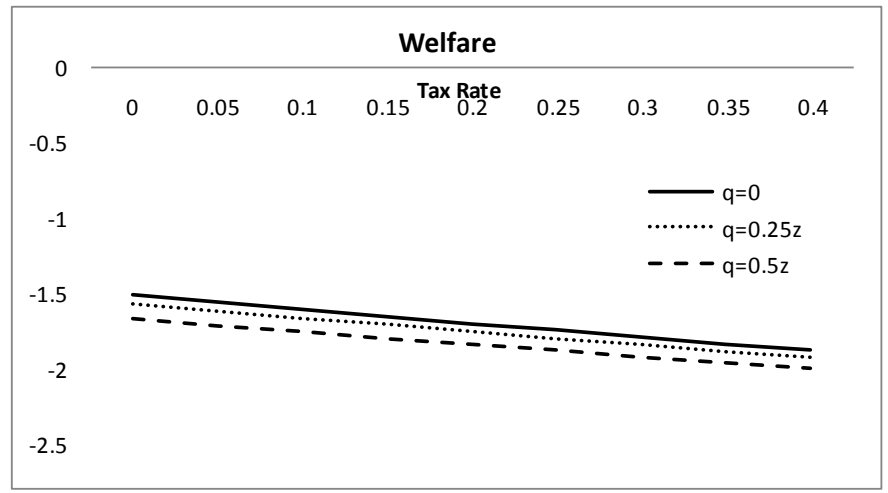

Fig.6-2. Welfare (Consumption Taxation)

This is an intuitive result. This numerical examples in this paper implies $n<1+r$ that is, an interest rate is larger than the fertility. ${ }^{10}$ Nevertheless, pension system exists in developed countries. This paper considers how the government collects tax revenue and provides child allowance to achieve the replacement rate aimed in developed countries.

In Japan, the government sets $50 \%$ as replacement rate. ${ }^{11}$ Without child allowance, income taxation can not achieve $50 \%$ as replacement rate. On the other hand, consumption taxation can achieve this replacement rate. However, if the government sets the replacement rate at 50\%, welfare level decreases largely, compared with no pension system. However, child allowance can achieve this replacement rate and does not decrease welfare largely. For examples, in the case of income taxation, child allowance provided a half of child care cost brings about $50 \%$ as replacement rate at $\tau=0.4$. In the case of consumption taxation, child allowance provided a half of child care cost brings about $50 \%$ as replacement rate at $\tau_{c p}=0.2$. Moreover, the welfare level with child allowance $\hat{q}=0.5 \hat{z}$ is larger than the one without child allowance even if both replacement rates are 50\%. Therefore, in terms of welfare, the government has to collect tax revenues with consumption taxation and provide child allowance.

Numerical examples shows that no pension system maximizes the welfare. However, if the pension system exists already, it is difficult to stop pension system because the welfare of older people in the period when the government stops pension system decreases surely. As shown by Fig.6-1 and Fig.6-2, the change from income taxation to consumption taxation at the fixed replacement rate pulls up the welfare level in the steady state. On the other hand, in transitional path, the welfare of older people may decrease. However, change to consumption taxation raises the fertility and then this increase pulls up pension benefit and welfare of older people even if consumption taxation is levied for the older people. Therefore, there exists the positive effect on the welfare of older people in transitional path. Then, the government can change the way to

10 This condision may be held because of no poplation growth in developed countries.

11 This replacement rate is considered in the case of standard households. 
finance pension benefit if the change from income taxation to consumption taxation raises the welfare in transitional path. $^{12}$

\section{Conclusions}

The analyses described in this paper set an endogenous fertility model with pension system and showed how tax burden and child allowance affect the replacement rate of pension, the fertility and so on. In Japan, the replacement rate is set at $50 \%$. Without child allowance, income taxation can not achieve this replacement rate as shown by numerical examples because an increase in income taxation decreases the fertility. If child allowance is provided, this replacement rate is achieved even if pension benefit is financed by an income taxation. We can consider another way to finance pension benefit as consumption taxation. Consumption taxation brings about $50 \%$ as replacement rate without child allowance because consumption taxation does not decrease the fertility. In addition, pension system prevents capital accumulation, so that household's income decreases because of decrease in wage rate. However, income taxation reduces capital accumulation and wage rate more than that in consumption taxation. Therefore, the fertility does not decrease in the case of consumption taxation and the replacement rate increases by any tax rates. In terms of welfare, the government should collects pension benefit with consumption taxation and provide child allowance to hold replacement rate $50 \%$.

\section{Acknowledgements}

Research for this paper was supported financially by JSPS KAKENHI Grant Number 21730159, 26380253. Needless to say, any remaining errors are the authors' responsibility.

\section{References}

De la Croix, D., \& Doepke, M. (2003). Inequality and Growth: Why Differential Fertility Matters?American Economic Review, 93(4), 1091-1113. http://dx.doi.org//10.1257/000282803769206214

Fanti, L., \& Gori, L. (2009). Population and Neoclassical Economic Growth: A New Child Policy Perspective,Economics Letters, 104, 27-30. http://dx.doi.org/10.1016/j.econlet.2009.03.014

Groezen, B. van, \& Meijdam, L. (2008). Growing Old and Staying Young: Population Policy in an Ageing Closed Economy, Journal of Population Economics, 21(3), 573-588. http://dx.doi.org/10.1007/s00148-006-0067-x

Groezen, B. van, Leers, T. \& Meijdam, L. (2003). Social Security and Endogenous Fertility: Pensions and Child Allowances as Siamese Twins, Journal of Public Economics, 87, 233-251. http://dx.doi.org/10.1016/S0047-2727(01)00134-7

Haveman, R., \& Wolfe, B. (1995). The Determinants of Children's Attainments: A Review of Methods and Findings, Journal of Economic Literature, 33(4), 1829-78.

Hirazawa, M., \& Yakita, A. (2009). Fertility, Child Care Outside the Home, and Pay-As-You-Go Social Security, Journal of Population Economics, 22(3), 565-583. http://dx.doi.org/10.1007/s00148-007-0153-8

Knowles, J. (1999). Can Parental Decisions Explain U.S. Income Inequality? Mimeo, University of Pennsylvania.

Laroque, G., \& Salanie, B. (2005). Does Fertility Respond to Financial Incentives?CEPR Discussion Paper Series, No. 5007. London: Center for Economic Policy Research.

Lutz, W. (1999). Will Europe Be Short of Children?Family Observer, European Observatory on Family Matters, European Commission, 8-16.

Milligan, K. (2002). Quebec's Baby Bonus: Can Public Policy Raise Fertility?Backgrounder. C. D. Home Institute, January.

Miyazato, N. (2010). The Optimal Size of Japan's Public Pensions: An Analysis Considering the Risks of Longevity and Volatility of Return on Assets, Japan and the World Economy 22, 31-39. http://dx.doi.org/10.1016/j.japwor.2009.06.001

Nishimura, \& Zhang, J. (1992). Pay-as-you-go Public Pensions with Endogenous Fertility, Journal of Public Economics, 48(2), 239-258. http://dx.doi.org/10.1016/0047-2727(92)90029-F

Oshio, T. (2001).Child-Care -- Reform in Pension System and the Fertility Rate(in Japanese), Quarterly of Social Security Research, 36-4, 535-546.

Oshio, T., \& Yasuoka, M. (2009). Maximum Size of Social Security in a Model of Endogenous Fertility, Economics Bulletin, 29(2), 656-666.

Sleebos, J. E. (2003).Low Fertility Rates in OECD Countries: Facts and Policy Responses, OECD Social, Employment

\footnotetext{
${ }^{12}$ As pointed by Hirazawa and Yakita (2009), decrease in tax burden may bring about Pareto improving condition. A decrease in tax burden raises the fertility and then pension benefit increases before decreasing tax rate. Then, the welfare in transitional path raises.
} 
and Migration Working Papers, 15.

Wigger, B. U. (1999). Pay-as-you-go Financed Public Pensions in a Model of Endogenous Growth and Fertility, Journal of Population Economics, 12(4), 625-640. http://dx.doi.org/10.1007/s001480050117

Yasuoka, M. (2006). The Relationship between the Fertility Rate and Tax policy (in Japanese), Quarterly Journal of Social Security Research, 42-1, 80-90.

Zhang, J., \& Zhang, J. (1998). Social Security, Intergenerational Transfers, and Endogenous Growth, Canadian Journal of Economics, 31(5), 1225-1241. http://dx.doi.org/10.2307/136468

Zhang, J., \& Zhang, J. (2004). How Does Social Security Affect Economic Growth? Evidence from Cross-Country Data, Journal of Population Economics, 17, 473-500. http://dx.doi.org/10.1007/s00148-004-0198-x

Zhang, J., \& Zhang, J. (2007). Optimal Social Security in a Dynastic Model with Investment Externalities and Endogenous Fertility, Journal of Economic Dynamics \& Control 31, 3545-3567. http://dx.doi.org/10.1016/j.jedc.2006.12.005

\section{$(\mathrm{cc})$ EY}

This work is licensed under a Creative Commons Attribution 3.0 License. 